\title{
Essais
}

ESSAIS

Revue interdisciplinaire d'Humanités

Hors-série 4 | 2018

Stanley Kubrick

\section{Inside the interpretative maze of The Shining (1980). The search for meaning in crisis}

Vincent Jaunas

\section{(2) OpenEdition \\ 1 Journals}

\section{Electronic version}

URL: http://journals.openedition.org/essais/622

DOI: 10.4000/essais.622

ISSN: 2276-0970

\section{Publisher}

École doctorale Montaigne Humanités

\section{Printed version}

Date of publication: 1 July 2018

Number of pages: 79-104

ISBN: 979-10-97024-04-8

ISSN: $2417-4211$

\section{Electronic reference}

Vincent Jaunas, «Inside the interpretative maze of The Shining (1980). The search for meaning in crisis », Essais [Online], Hors-série 4 | 2018, Online since 01 December 2019, connection on 10

December 2020. URL : http://journals.openedition.org/essais/622 ; DOI : https://doi.org/10.4000/ essais.622 


\title{
Inside the interpretative maze of The Shining (1980). The search for meaning in crisis
}

\author{
Vincent Jaunas
}

"People can misinterpret almost anything so that it coincides with views they already hold" ${ }^{1}$, Stanley Kubrick told Michel Ciment regarding The Shining. At the time, Kubrick could not have imagined that for almost 40 years, The Shining would arouse such a myriad of interpretations, many of which bordering on pure speculation. And yet the director proves how aware he was as to the challenge his film represented for whoever wished to give it an excessively coherent interpretation. Today, one only needs to explore online forums for a few minutes to observe how spectators are capable to go beyond the limits of hermeneutics to detect supposed hidden meanings in the film. The Shining is widely regarded as un film à clef, the hidden secrets of which only a handful of sufficiently smart and tenacious spectators could discover.

The documentary Room 237 provides a handful of examples ${ }^{2}$ of what we shall call overinterpretations. We may think of the theory arguing that the director of 2001: A Space Odyssey disseminated clues in The Shining to secretly admit he had shot a fake Moon Landing for the US government. I would also like to refer to the publication in 2014 of the book Kubrick's Code, in which Isaac Weishaupt argues that the whole filmography of the director aimed at warning the world against a secret plot orchestrated by the illuminati for world dominion ${ }^{3}$. The Internet also hosts a website, saturndeathcult.com, in which we may find an analysis of The Shining as revealing the existence of an international occult sect organised around "paedophilia and planned ritualistic transmutation of mankind"4.

1 Stanley Kubrick, Kubrick on The Shining, an interview with Michel Ciment, 1980: http://www. visual-memory.co.uk/amk/doc/interview.ts.html (last visited 03/11/17).

2 Rodney Ascher, Room 237, Tim Kirk Production, 2012.

3 Isaac Weishaupt, Kubrick's Code, CreateSpace Independent Publishing Platform, 2014.

$4 \mathrm{http}: / /$ saturndeathcult.com/crimes-of-the-saturn-death-cult/stanley-kubrick-and-the-saturndeath-cult/ (last visited 01/11/17). 
In The Shining, the motif of the maze may seem to legitimize those spectator-detectives in their investigations. In a maze, one must show perseverance and cunning to overcome the obstacles laid down by the designer in order to reach the centre. The omnipresence of the motif of the maze may thus convince the most tenacious spectators that if they keep digging beyond the surface, they may eventually reach a hidden centre and unlock a secret reading strategy that would turn the film into a limpid message.

I would like to argue the maze of The Shining suggests that there is no hidden centre, no secret key which would unlock all its mysteries and provide a clear reading. As Roger Luckhurst wrote, "one must chart the structure of the maze rather than arguing there is only one way through it"s. However, in The Shining, the obsessive hermeneutic craze of the spectator seems to be encouraged as well as challenged, so that one runs the risk of getting lost in an interpretative dead-end. By creating a film-maze, Kubrick integrated the spectator's quest for meaning at the core of his aesthetics, to better question it.

In this labyrinthine film, there is no one good path to follow, at the exclusion of all others. The film is what Umberto Eco calls an open work, for it enables "the increase and the multiplication of the potential meanings of the

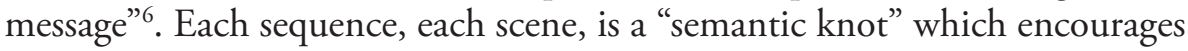
spectators to multiply viewing hypotheses.

As a result, the progression of the film is not linear and does not culminate in a final revelation that would enable one to select one of those hypotheses over all others, as in a detective film. On the contrary, it seems that each scene opens a new interpretative path, and that each viewing hypothesis is eventually condemned to look like a dead-end. In this regard, one should keep in mind that we do see the centre of the diegetic maze, as Wendy and Danny play in it (Figure 1). However, this centre turns out to be an open area, filled with various potential paths to explore. The centre is thus not a closing one, but another opening. This constant opening of the film, which prevents any restrictive interpretation, culminates in the final scene. According to Laura Mulvey, "There are two grand conventions of narrative closure, devices that allow the drive of a story to return to stasis: death or marriage"

In The Shining, however, the narrative closure which is Jack's death is instantly overcome with an extra scene, adding an excess of semantics compared with the Hollywood convention. The camera zooms forward through a hallway, a space open on each side which contrasts with the single paths available in a maze, and then onto a wall filled with photographs. It finally reveals a picture

5 Roger Luckhurst, The Shining. London: BFI/Palgrave, 2013, p. 12.

6 Umberto Eco, L'ouvre ouverte. Paris : Éditions du Seuil, 1979, p. 61.

7 Laura Mulvey, Death $24 x$ a second: stillness and the moving image. Islington: Reaktion Books, 2006, p. 71. 
from 1921 in which Jack seems mysteriously alive, out of our reality (Figure 2). An apparent sense of closure is thus contradicted with the opening of countless new potential interpretations. The polysemy of the film is therefore established through the divide between narrative closure (Jack's death) and the lack of semantic closure (his death certainly does not attenuate the hermeneutic craze of the spectator trying to figure it all out). One may keep in mind that the film's final screenplay contained an extra ending scene, in which Ullman visits Danny and Wendy at the hospital ${ }^{8}$. This scene would have preceded the zooming on the photograph, and would have added an extra sense of closure by making the audience sure Danny and Wendy were alive and well. Deleting this scene thus focused the ending on the semantic opening provided by the revelation of the photograph. Such an open film therefore seems to exclude any possibility of adopting a definitive interpretation of the film, excluding all others. To respect the intention of the film, any attempt to interpret it must therefore acknowledge its own limits and the coexistence of equally valid hypotheses.

This ultimate scene is one of the main alterations from Stephen King's novel. All the major alterations of the screenplay follow the same path and maintain a narrative clarity while opening the semantic potential of the work. Michel Chion explains how the changes made for the European version of the film -a shorter version, modified after the American release- tend to suppress the causal links binding the sequences together, thus making of each scene a separate part of a puzzle which it is up to the viewer to piece together'.

If the film therefore celebrates the potentially unlimited semantics of cinema, The Shining may lose some spectators through this excess of potential meanings. The hermeneutic confusion of the spectator is heightened by the loss of spatiotemporal bearings within the hotel. Indeed, spatial disorientation within the maze-like structure of the hotel is coupled with temporal disorientation. The cartons of the film are a case in point. They first indicate specific time markers. "Closing Day" thus refers to a specific date, October $30^{\text {th }}$, and a specific event, i.e. the closing of the hotel for the winter season. Later on, however, the captions only refer to deictic markers like "Wednesday", which can only make sense if one knows when it was written and by whom, which is not the case in a movie with no established external narrator. This Wednesday could refer to any Wednesday. Therefore, as the film moves forward, the feeling of dread provoked by the dilatation of time mixes up with a feeling of temporal confusion. This confusion is of course accentuated by the coexistence of three different timelines -the 1980's, 70's and 20's- across which Jack evolves effortlessly.

8 Anon, "The Shining Screenplay", SK/15/1/38, Stanley Kubrick Archives, University of the Arts London.

9 Michel Chion, Stanley Kubrick: L’humain, ni plus ni moins. Paris : Cahiers du Cinéma, 2005, p. 398-403. 
One's impossibility to hang on to any set of codes to make sense of what one sees and hears is a powerful source of terror in the film. The multiplicity of semantic associations such a film entails therefore creates a highly particular form of fright that one may call, following Umberto Eco's expression, "the vertigo of the labyrinth" ${ }^{10}$. This specific horror encourages some spectators to dig into the film, to overinterpret it, in the hope of finding some secret code that would relieve the tension of openness, and bring a sense of definite, all-encompassing closure.

According to Umberto Eco, such an interpretative strategy is inherited from a long tradition of hermetic thinking, which cultivates secrecy: according to this tradition, "a secret knowledge is a deep knowledge. Thus, truth becomes identified to the unsaid or the obliquely said and must be understood beyond appearances" ${ }^{11}$. The power of attraction of such a way of thought is undeniable. One who can unlock mysteries and decode secrets becomes in his turn the bearer of some unique knowledge, as Georg Simmel -quoted by Eco- explains: "the secret gives its bearer an exceptional position and is attractive for purely social reasons. This attraction is fundamentally independent from what the secret reveals" ${ }^{12}$. Thus, for hermetic spectators, the one who would try hard enough and eventually manage to find the key for the film's explanation would be gratified with a secret all the more attractive because no one else possesses it. The maze-like structure of the film, seen as a challenge to the audience, would be enough to attract hermetic interpretations.

Moreover, the reputation of Stanley Kubrick certainly enhanced this hermeneutic craze. In the 1980's, the director was already widely perceived as a recluse genius, a perfectionist whose unwillingness to divulge the meanings of his films to the media only increased his aura. The attractiveness of such a reputation for the hermetic spectator is clear: faced to such a genius, nothing can be due to chance. Consequently, if some aspects of The Shining are not comprehensible, it means they must hold some hidden meanings.

Kubrick seems to play as much with his reputation as with the codes of the horror genre by displaying an overexposed horror film, in which everything seems hidden in plain sight. Michel Chion considers the lighting of The Shining to go against the entire tradition of horror cinema by displaying no shadows: "not a single spot of darkness remains" ${ }^{13}$. Several scholars underline how the film characters struggle with vision, from Danny's "shining" glimpse of the elevator overflowing with blood to Jack's hallucinated gaze at the woman in Room 237. Both Jean-Baptiste Thoret and Sam Azulys note how Jack's eye is

10 Umberto Eco, De l'arbre au labyrinthe. Paris : Grasset, 2010.

11 Umberto Eco, Les limites de l'interprétation. Paris : Grasset, 1992, p. 14.

12 Georg Simmel, quoted in ibid., p. 54.

13 Michel Chion, op. cit., 2005, p. 391 (my translation). 
submitted to an "excess of visibility"14. For the viewer as well, such extra-visibility is troubling, as it creates the uncanny feeling that everything is a sign; that each frame, each element within a frame, potentially signifies something and has to be taken into account. As a result of the depth of field in the pantry scenes, for instance, a can of baking powder branded with a logo displaying a Native American is clearly visible in the background shelves (Figure 3), which leads Bill Blakemore to interpret the film as a complex network of signs referring to the genocide of Native Americans ${ }^{15}$. The spatio-temporal and narrative complexities of the film, in which everything nonetheless appears to be explicitly shown, thus come to inspire a highly specific sense of dread. The horror of The Shining is not a horror of the hidden, but a horror of the too visible, by which viewers feel dread when faced with an apparent surplus of information they are invited to decipher. Hence the many overinterpretations using film stills ${ }^{16}$.

I would like to add, however, that the links between The Shining and hermetic thought run deeper. Kubrick and his collaborators built a work which, thematically as well as aesthetically, relates to hermeticism. In this regard, we may keep in mind that, according to Umberto Eco, the director once considered ${ }^{17}$ adapting the author's novel Foucault's Pendulum (1988) which deals with hermetic thought: the hero, both fascinated and critical towards hermetic thought, ends up falling under its spell and eventually interprets the world as resulting from a secular plot orchestrated by the Templars to gain world dominion. In The Shining, Jack Torrance fits all the conditions of the hermetic spectator: in front of a scary, multi-layered world he cannot control, Jack will fall into an all-encompassing interpretative strategy which gives him back an illusion of control: it is by killing his family, the source of all his problems, that Jack will finally be a part of the careless high society he aspires to, and that the ghosts tease him to become a part of.

The many mirror effects spread throughout the film arouse the suspicion that what the senses can perceive is only the surface of things, and that beyond it lie depths which cannot be grasped, embodied by the ghostly presence in the hotel. This is notably the case in Room 237: when a young naked woman gets out of

14 Jean-Baptiste Thoret, Remarques à propos de The Shining de Stanley Kubrick. Simulacres $\mathrm{n}^{\circ} 01$, 1999, p. 102 ; Sam Azulys, Stanley Kubrick: Une Odyssée Philosophique. Chatou : les éd. de la Transparence, 2011, p. 301.

15 Rodney Ascher, Room 237, op. cit., 2012.

16 Most interpretations in Room 237 are thus based on either freeze frames or various audiovidual manipulations permitted by DVDs and computers. This tendency also partly explains the recent increase in overinterpretations of the film, as everyone may now manipulate images using modern technologies.

17 Filippo Ulivieri, Waiting for a Miracle: a Survey of Stanley Kubrick's Unrealized Projects. Cinergie: il cinema e le altre arti, ${ }^{\circ} 12$, 2017. https://cinergie.unibo.it/article/view/7349/7318. Ulivieri suggests such a project may never have been seriously considered by Kubrick. Eco's claim nonetheless underlines a shared fascination with hermeticism for both artists. 
the bathtub, Jack lets himself be drawn to her, and kisses her in a confident, serene embrace. It is only by watching the woman's reflection in the mirror that Jack discovers another aspect of this scene, hideous this time: the woman turns out to be a rotting corpse. The only time Jack actually fears the ghosts of the hotel is thus triggered by his look in the mirror. Afterwards, Jack ceases to look at mirrors and to confront himself to what lies beyond appearances (Figure 4).

Instead of seeing the ghosts for what they are, he no longer distinguishes them from the living, and walks around a 1920's party without displaying any sign of doubt as to the ontological status of what he hears or sees ("anything you say Lloyd, anything you say"). During this party, Jack accompanies Delbert Grady to the bathroom and seems to go through the looking glass. In the bathroom, Jack faces the mirrors but he never explicitly looks at them, as his eyes are fixed on Grady. At times he seems to catch sight of the mirror reflections, but the camera never reveals the reflection itself. Three $180^{\circ}$ shots and countershots then reverse the position of the characters and objects within the frame as Grady asserts Jack is one of them. Without access to what the mirrors display, the audience is encouraged to consider that this time, Jack fails to see, or refuses to see, the oscillation of his own situation. Jack's own journey through the looking glass is announced earlier in the film, when a zoom backwards reveals the shot did not show Jack but his reflection in a mirror. Mirror images are flat and two dimensional, its depths are mere illusions, thus suggesting Jack gets trapped in a world of reflections and appearances. Jack's path is thus similar to that of the hermetic spectator who, frightened by the sense that what one sees is only the surface, digs ever deeper only to restore an appearance of perfect coherence through overinterpretation.

In The Shining, however, the feeling of dread does not arise from the ghosts as much as from Jack himself. He enters a murderous rage when he decides to close his eyes to the frightening multi-layered reality, and becomes in the process the tool of the ghosts. Faced with a world he cannot fully comprehend, Jack sticks to an illusory interpretative strategy. If the immensity of the world and man's impossibility to comprehend it may be terrifying, Kubrick suggests that refusing to face this fact is even worse and leads to madness.

Jack's hermeneutic blindness is opposed to the clear-sightedness of Danny, which results from his gift, his "shining". Danny never stops perceiving the ghosts in all their ungraspable alterity. Each of his visions are marked by audiovisual effects insisting on the supernatural character of the ghosts (Figure 5): a progressive zoom towards the character's face, shaking with fear, and an oversaturated high pitched sound. His first vision occurs before his arrival at the Overlook. Danny is in the bathroom looking at a mirror. During this first vision, the brevity of the images is interspersed with close ups of a terrified Danny, shot before a black background which disconnects him from all diegetic spatiotemporal situation. Like Jack in Room 237, Danny fears this new layer of 
the world which he glimpses at as he shines, but unlike his father Danny does not shy away from it by mixing up the status of those visions with that of his everyday reality. His visions maintain their fantastic quality. Danny experiences them through his alter ego Tony ("the little boy that lives in my mouth"). Tony prevents Danny from going through the looking glass by underlining the alterity of his visions. Even at the end of the film, Tony takes over to warn Wendy of Jack's murderous intents -thus treating Jack as another fantastic vision, which points to the fact the father is now trapped inside this other layer of reality. To warn Wendy, Tony writes Murder backwards, a word that needs to be read through a mirror: up until the end, Danny does not reduce the fantastically ungraspable nature of his vision to a more understandable, everyday reality. This other layer remains fundamentally Other, unthinkable, uncontrollable. Thus, when Danny actually encounters ghosts in the hotel, he never shares Jack's madness and keeps considering these beings as inherently Other.

Danny's visions overflow with meanings that neither the child nor the viewers can fully comprehend. Conversely, Jack's world becomes more and more limpid as the film progresses and he gets stuck into a simplistic interpretation: all his problems revolve around his family, and he needs to "correct" them to reach a blissful harmony with the hotel dwellers. This interpretation is forced upon reality, in a series of assertions terrifying because of their very simplicity, such as his famous claim that "all work and no play makes Jack a dull boy". Jack's increasingly simplistic worldview climaxes in the end, as he becomes an animal -as underlined by Nicholson's howling, screaming and drooling performance- as well as a child, quoting the three little pigs.

Faced with a contingent world overflowing with ungraspable signs, Kubrick therefore opposes two viewing models, Jack's and Danny's (Figure 6). Like them, spectators have to face an open work, multi-layered and infinitely open to interpretation. Like Jack, hermetic spectators deny this multiplicity to look for a secret key to decipher the work and unify it into an all-encompassing, limpid narrative. In the process, they may, like Jack, get lost within the semantic maze of the film, "for ever and ever", by digging ever deeper into the work in an attempt to, paradoxically, better negate its depth.

Danny, on the other hand, appears to be an ideal viewer. In the last confrontation with his father, he runs into the various paths of the maze and manages to get out of it alive. Instead of looking for the right path, Danny accepts the complexity of the maze and plays with it. He decides to walk back on his tracks. Danny cunningly elaborates a strategy -using his own tracks- to get out of the labyrinth without trying to solve its mysteries. Its multiple paths enable Danny to hide himself.

We have seen how, all along the film, Danny does not deny the fantastic quality of his horrific visions, their alterity and therefore the impossibility to make sense of them. The ideal viewer of the film is therefore a child, characterized by 
his smallness in the gigantic setting he evolves in. From the very opening of the film, all the characters seem like nothing compared to the sublime immensity of the landscape, which shrinks mankind to the tiny spot which is the car within the overall frame. Once inside the Overlook Hotel, the size of the building is constantly emphasized in the scenes involving Danny. In the game room during his first scene within the Overlook, Danny must step on a chair to take down the darts he was playing with, since the target is too high. When he walks around the kitchen, Danny's body barely occupies the lowest quarter of the frame, whereas Wendy and Halloran fill three quarters of it. We may add that in The Shining, the ceiling is always visible in the frame. If it seems to lock the characters in a cage -a signature Kubrick effect- it also emphasizes the hugeness of the Overlook. This feeling is particularly strong when Danny rides on his tricycle. The low position of the Steadicam follows Danny at his level, whereas the breadth of the frame is blocked by the narrow corridor, which accentuates in an almost anamorphic distortion the dreadful immensity of the hotel (Figure 7).

However, Danny manages not to be crushed by the Overlook. He uses its immensity to his advantage. When Jack runs after him, he uses his small size to crawl out of the bathroom window, and then hides himself in the kitchen cupboards. In the early scenes, Jack also seems crushed by the size of the hotel -all the characters do in the first tracking shots crossing the great hall. But instead of using it, Jack tries to reduce this immensity, and to take control of the film space. Nicholson's paroxysmal acting gives his character an aura that Kubrick accentuates by making him fill the frame, in various striking closeups (Figure 8). When he's locked in the pantry, an extreme high-angle shot has Jack fill the whole frame with a monstrous charisma that erases the hotel around him. The most famous shot of the film is another telling example. Jack's face appears through the door he just tore down with an axe, so that Jack literally destroys the architecture of the hotel and invades the frame.

The two relations of these characters with their environment is elegantly underlined in their differing ways of dealing with the maze. Looking at the maze's model, Jack tries to distance himself from the maze's depth, to tower above it and to dominate it, whereas a cut connects this shot to a plunging low angle shot of the maze. The viewer finally understands he is now looking at the outside maze, in which Danny and Wendy look like mere dots and enjoy getting lost in the place, rather than dominating it. "I didn't think it was going to be this big, did you?" says Wendy smiling. The film's over-exposure provides an almost constant depth of field which accentuates the three dimensional quality of the hotel, and of the outside maze. Jack's attempt to dominate space is also an attempt to negate its depth, to make the image a flat one. Jack's previously mentioned association with mirrors, with their fake sense of depth, also underlines his wish to flatten the image, to stick to a reassuring two-dimensionality (Figure 9). 
It is finally Jack who, after his attempt to control space, becomes entrapped in it and dies whereas Danny escapes. Jack follows Danny's snow tracks without thinking they might fail to lead to his son. Those Snow tracks are signs that Charles Pierce defined as indexes. An index, Mulvey explains, is defined as "a sign produced by the thing it represents" 18 . According to the critic, "the specificity [of film] is grounded in the index" ${ }^{19}$. Consequently, Jack gets lost because in The Shining, an index can prove to be a false lead, a sign which disorients when the viewer blindly trusts its direct relation to the thing it signifies. Jack, like the hermetic viewers, blindly follows signs instead of questioning their link with what they represent (Figure 10).

Jack's rigid interpretative processes therefore parallel the hermetic spectators'. By attempting to reduce the semantic polysemy of the film into a single pre-established interpretative hypothesis, the hermetic viewer associates each signifier with a single signified. This type of viewer does not question the amalgam of the cinematographic index with a limpid language, here to deliver a message. The labyrinth which the film is is therefore denied its aesthetic quality, and becomes considered as a symbolic text aiming at delivering a fixed, stable message about the real world, like the denunciation of a secret sect or the admission of a secret conspiracy with the American government. In this regard, the bedroom scene in which the viewer believes to be looking at Jack whereas he is actually looking at his reflection acts as a metafilmic equivalent of Jack's pursuit of snow tracks. Kubrick indicates his spectators they must be careful not to mix up an indexical sign with what it represents. In other words, one must be aware not to equate representation with reality. Cinema is an art of representation and should not be seen as holding a clear and direct message about reality. The best way to deal with a contingent world, The Shining suggests, is to create a work of art which embraces its openness, its multiplicity, and becomes an interpretative maze. Any viewer mixing up an index and the reality it represents blinds himself from the multiplicity of film as well as from the multiplicity of reality itself.

The final photograph shows Jack stuck forever within the Overlook hotel (Figure 11). Laura Mulvey insists on the inherently uncanny quality of photography. Photography captures a slice of time which becomes fixed, out of duration, "as a trace of the past that persists into the present" ${ }^{20}$. Jack's wish to escape the contingency of his world and to gain total control finds here an ironic conclusion: the price to pay to remain in the Overlook for ever is to become a fixed image oneself, to become the image of death. Furthermore, Mulvey's claim takes an extra dimension in The Shining: Jack remains fixed in an epoch that is

18 Charles Pierce, quoted in Laura Mulvey. Death $24 x$ a second: stillness and the moving image, op. cit., 2006, p. 9.

19 Ibid.

20 Ibid., p. 31. 
not his. Jack becomes an aberration, a necessarily ungraspable representation, just like the ghosts he did not perceive as such. The hermetic viewer who would follow on Jack's footsteps is therefore warned: Jack's incapacity to accept the complex nature of the signs surrounding him has condemned him to be locked in a system of self-referential signs, seemingly disconnected from any reality.

Danny, as an ideal spectator, offers instead an open worldview, in which any vision occupies a level of reality of its own, and retains its mysteries. Danny observes his snow tracks and sees in it complex signs he can play with. Our exploration of The Shining as a semantic maze thus leads me to conclude that the film balances two opposite worldviews, Jack's and his son's. The Overlook's ghosts, not unlike the monolith of 2001, are signs of a radical alterity, glimpses of an ungraspable layer of reality. Faced to this reality which overflows -like the elevators overflow with blood-and that goes beyond any possibility of human comprehension, two modes of perception oppose each other.

The Shining is therefore a challenge for the viewer. Faced with the depths of the maze, Hermetic spectators run the risk of digging into the film to, paradoxically, negate its depths and stick to a limpid, reductive reading hypothesis. The spectators who follow Danny's worldview, on the other hand, will have to open their eyes to a world that is multi-layered, ungraspable and incomprehensible. If The Shining shows how this revelation may be a source of terror, it is the price to pay to be able to avoid the trap of reducing it to a controllable, well-defined entity. Given the immensity of the labyrinth, the film fosters a worldview defined by humility, one in which human intelligence has to face its own limits to get out safely.

\author{
Vincent Jaunas \\ Laboratoire CLIMAS \\ Université Bordeaux Montaigne \\ vincentjaunas@hotmail.com
}

\begin{abstract}
This essay examines the hermeneutics of The Shining (1980) in the light of the manifold overinterpretations that became apparent since the advent of internet forums and gained visibility with the release of Room 237 (Rodney Ascher, 2012). I suggest that, as highlighted by the motif of the labyrinth, Kubrick constructed a hermeneutic maze in which Jack -subject to hermetic thought- loses himself while Danny, whose humility enables him not to fall into the traps of an organising reason striving to make sense of a world impervious to human logic, escapes. In doing so, The Shining envisages its own reception through the staging of two conflicting viewing models.
\end{abstract}

\title{
Keywords
}

Kubrick, The Shining, hermeneutics, overinterpretation, reception theory. 


\section{Résumé}

Cet article propose de réévaluer les enjeux herméneutiques de Shining (1980) à l'aune de la vague de surinterprétations du film, manifeste depuis les années 2000 et l'avènement des forums internet et ayant gagné en visibilité depuis la sortie du documentaire Room 237 (Rodney Ascher, 2012). Nous suggérons que, comme indiqué par le motif du labyrinthe, Kubrick envisagea son film comme un dédale herméneutique dans les méandres duquel se perd Jack, personnage soumis à une pensée hermétique, tandis qu'en réchappe Danny, dont l'humilité lui permet de ne pas sombrer dans la folie qui guette ceux dont la raison ordinatrice cherche à faire sens d'un monde irréductible à la logique humaine. Ce faisant, le film envisage sa propre réception en mettant en scène deux modèles de lecture conflictuels.

\section{Mots-clés}

Kubrick, Shining, herméneutique, surinterprétation, réception. 


\section{NOTICE BIOGRAPHIQUE}

Vincent Jaunas est doctorant contractuel à l'Université Bordeaux Montaigne. Sa thèse porte sur "La subjectivité dans l'œuvre de Stanley Kubrick ", sous la direction de Jean-François Baillon. Avec ce dernier, il a co-organisé en 2016 le colloque international "Stanley Kubrick : nouveaux horizons ", puis co-dirigé le présent ouvrage. En 2017, il a publié dans le $\mathrm{n}^{\circ} 12$ de la revue cinergie Acting Out of the World: The Distancing and Underplaying of the Main Actors in 2001 et Eyes Wide Shut, puis en 2018, Life Functions Terminated: The Aesthetics of Distanced Subjectivity in 2001, dans l'ouvrage collectif Understanding (édité par J. Fenwick, édition Intellect). 


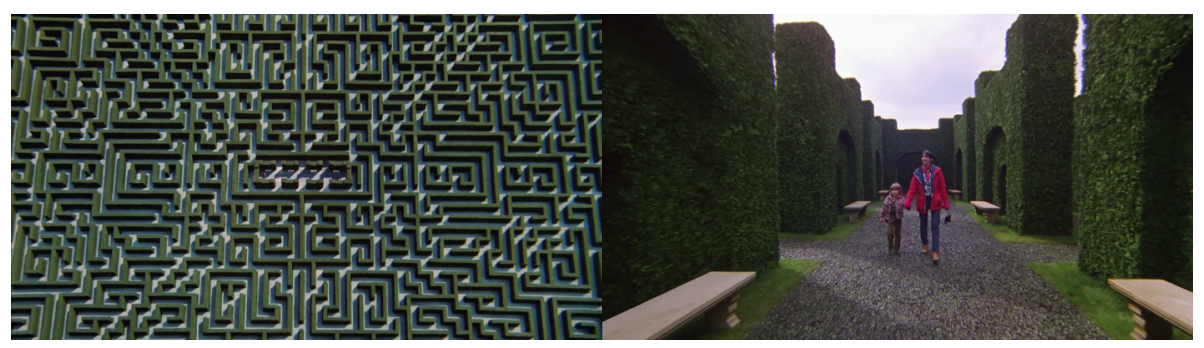

Figure 1: The maze and its open centre.

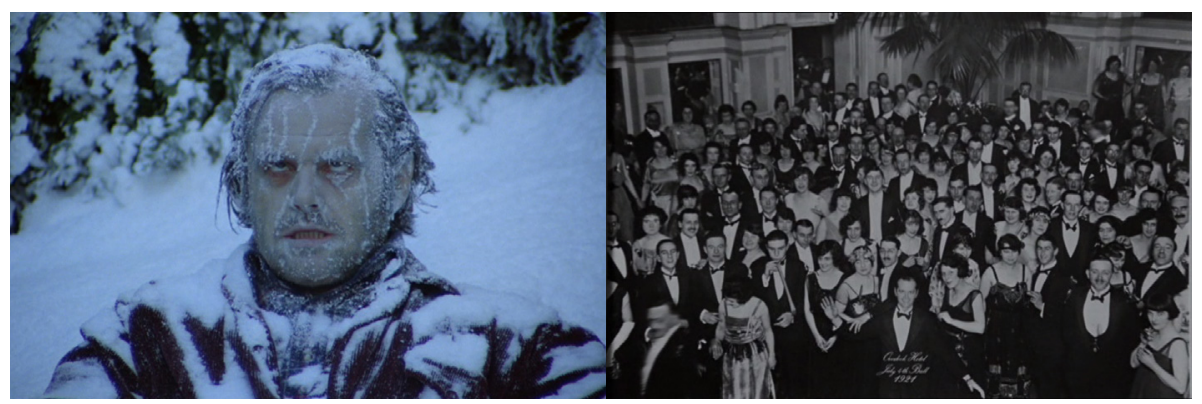

Figure 2: An ending that denies closure.

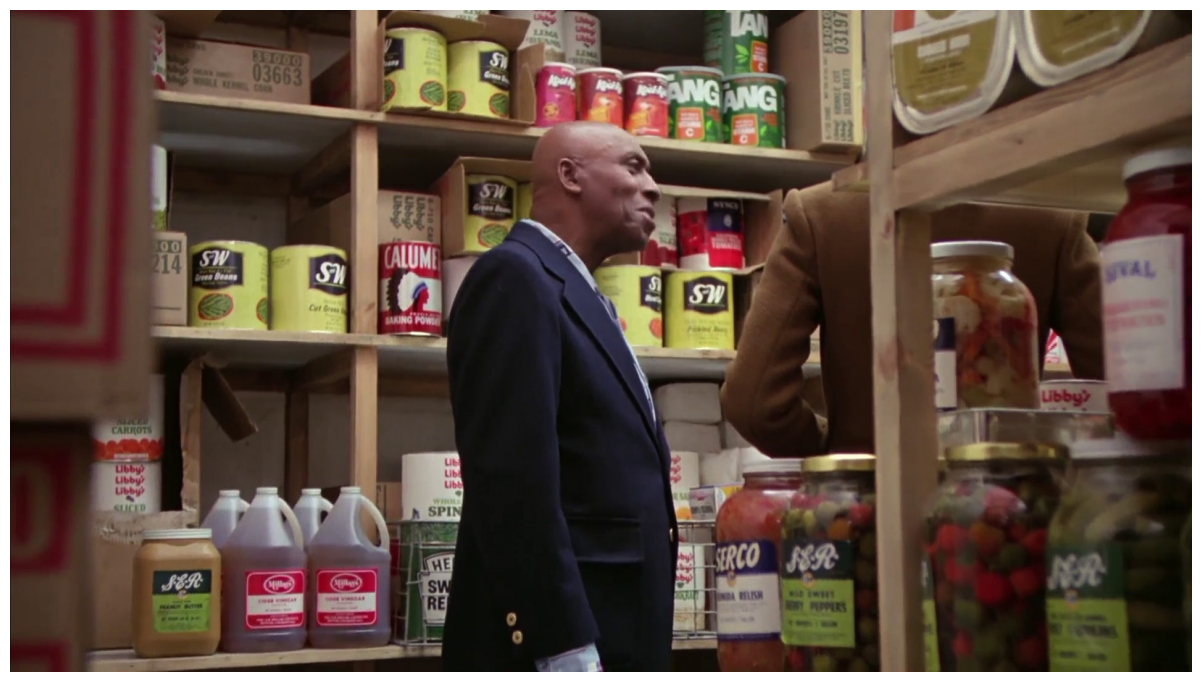

Figure 3: An excess of visibility. 


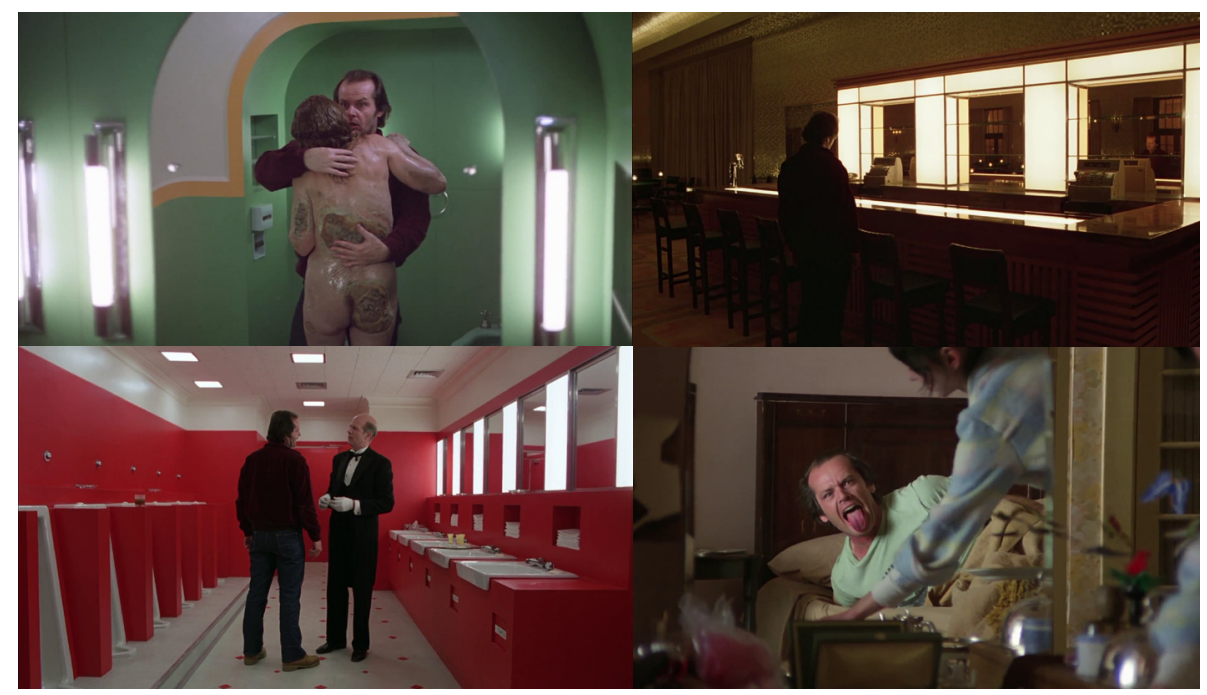

Figure 4: Jack and mirrors.

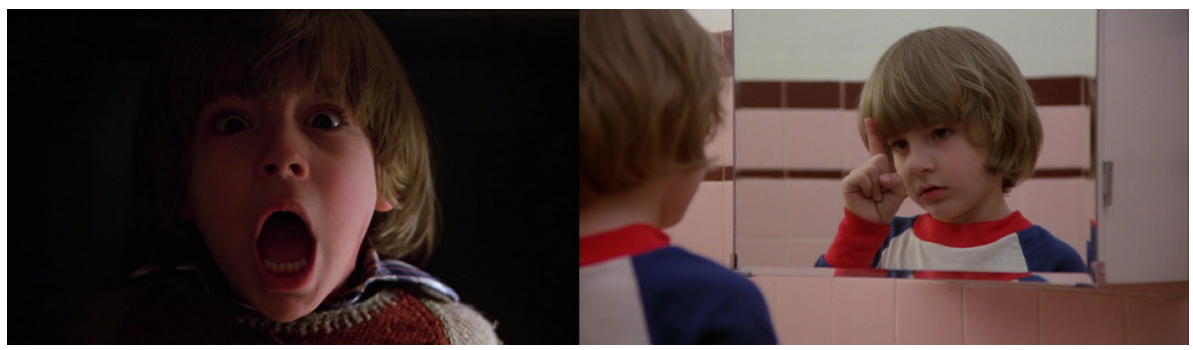

Figure 5: Danny's visions of alterity.

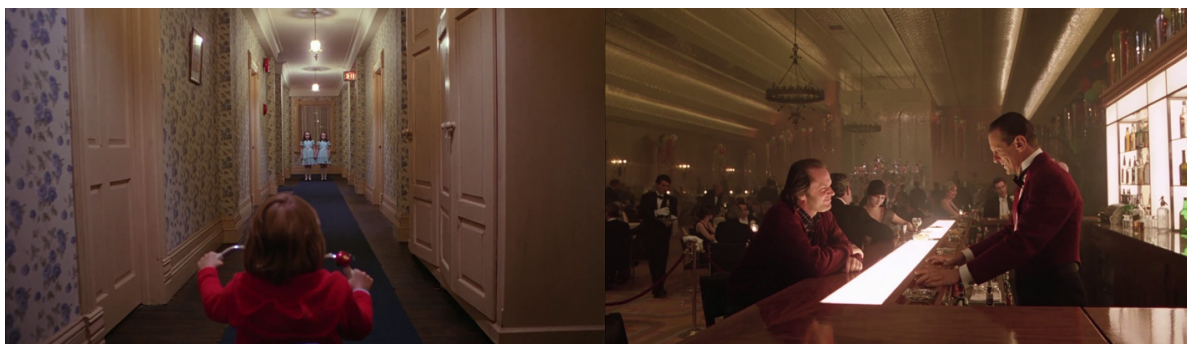

Figure 6: Two conflicting viewing models. 


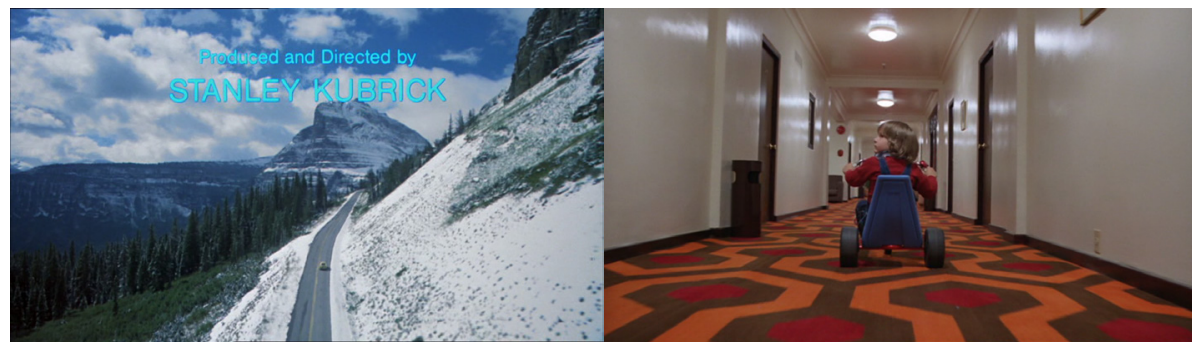

Figure 7: A dwarfed mankind.

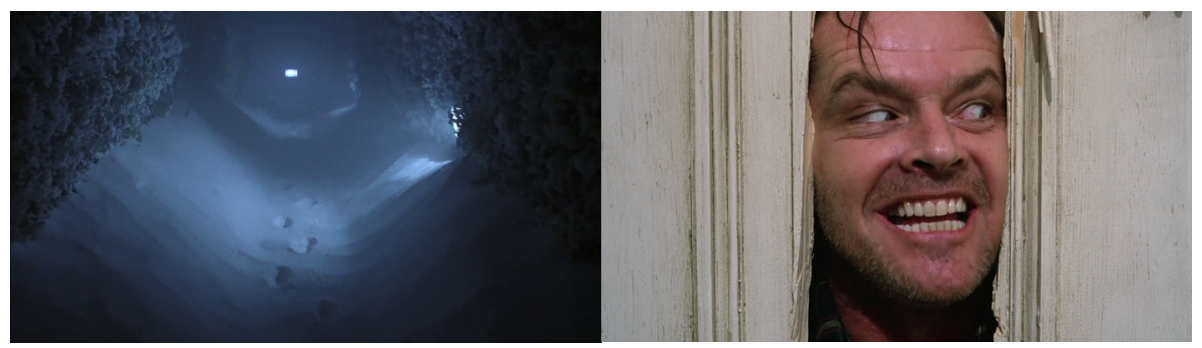

Figure 8: Two opposed relations to space.

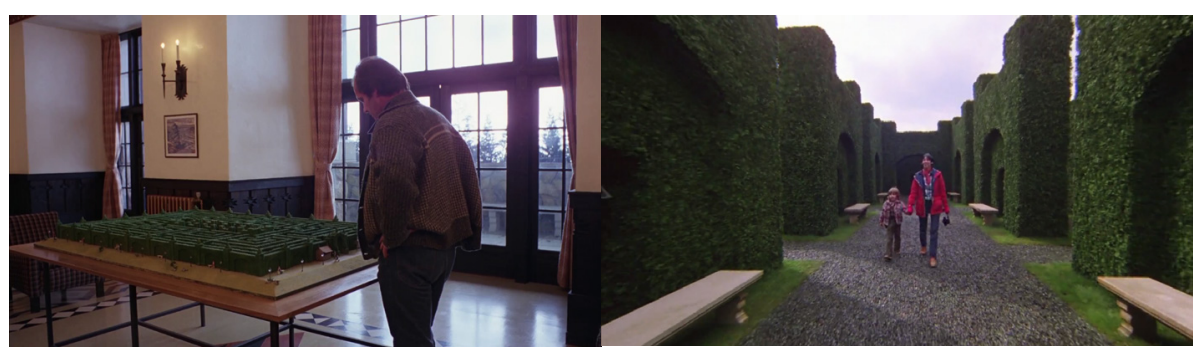

Figure 9: Towering over the labyrinth or enjoying its depth. 


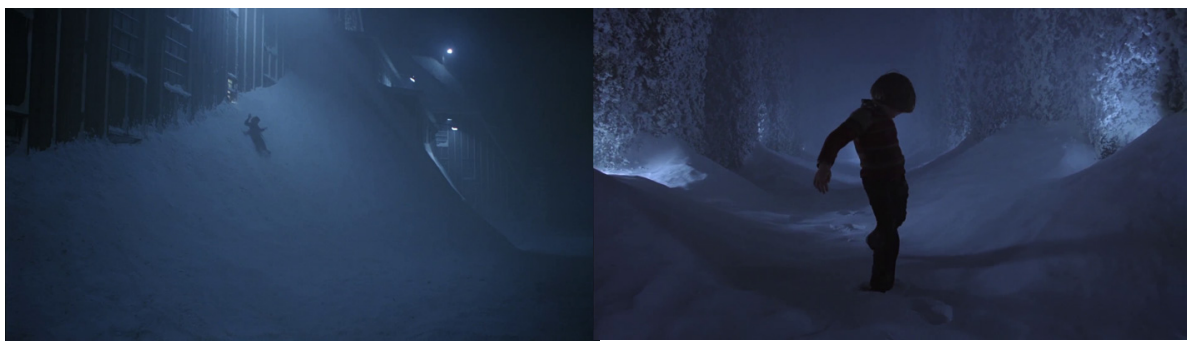

Figure 10: misleading signs.

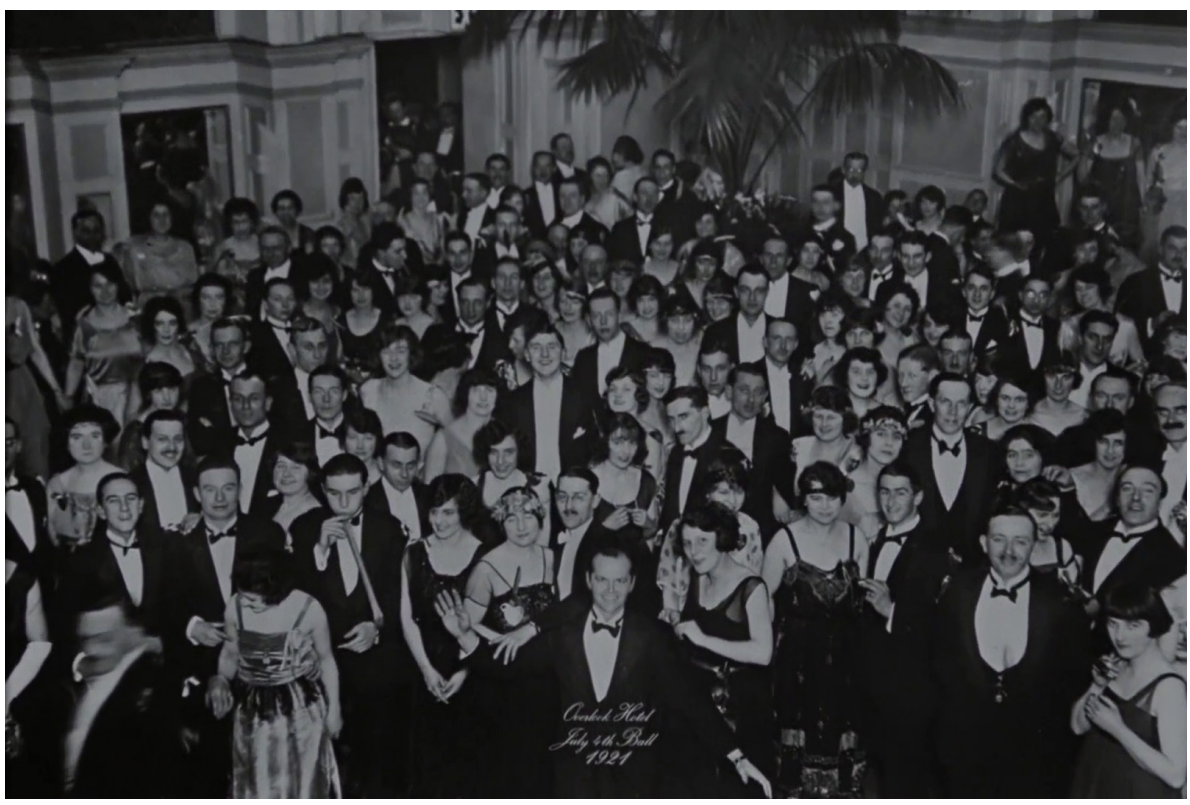

Figure 11: An uncanny photograph. 